\title{
Assessment of the Effect of Plant Spacing on Runoff, Soil Erosion and Soybean Yield (Glycine Max L)
}

\author{
${ }^{1}$ Aga T.A $;{ }^{2}$ Jijingi H.E; ${ }^{3}$ Anyadike C.C \\ ${ }^{1}$ Department of Agricultural Engineering Services, Ministry of Agriculture and Natural Resources, Makurdi. \\ ${ }^{2}$ Department of Soil Science and Land Resources Management, Federal University Wukari - Taraba State, Nigeria. \\ ${ }^{3}$ Department of Agricultural and Bioresources Engineering, University of Nigeria, Nsukka
}

\begin{abstract}
The study of the effect of different plant spacing on runoff, soil erosion and soybean yield was conducted in Yandev, Gboko, Benue State, Nigeria. The site for the experiment was manually cleared of its natural vegetation. The experiment was performed on nine $2 \mathrm{~m} \times 1 \mathrm{~m}$ micro plots of fine tilt and slope $3 \%$. Boundaries of burnt bricks were built round each micro-plot to prevent the entry of runoff from adjacent plots and land. Collecting pits were excavated at the lower end of each micro-plot in the direction of the slope and plastic bucket collectors of 40 litres were installed to catch runoff and soil erosion sediments from the micro plots. The size of each micro plot was $2 \mathrm{~m}^{2}$. The experiment consisted of three treatments replicated three times. Treatment one $\left(T_{1}\right)$ with plant spacing of $20 \mathrm{~cm} \times 20 \mathrm{~cm}$, treatment two $\left(T_{2}\right)$ with plant spacing of $30 \mathrm{~cm} \times 30 \mathrm{~cm}$ and treatment three $\left(T_{3}\right)$ with plant spacing of $40 \mathrm{~cm} \times 40 \mathrm{~cm}$. Runoff and soil erosion data were determined after each rain storm by measuring the runoff with a $1000 \mathrm{ml}$ measuring cylinder. The soil erosion was determined by measuring the oven dried soil erosion sediment with an electronic weighing balance. The soybean yield was determined by weighing the harvested and sun dried soybean grain at a moisture content of $12.6 \%$ using an electronic weighing balance. The values of the runoff from the different treatments are $202.50 \mathrm{~m}^{3} / \mathrm{ha}$ for treatment one $\left(T_{1}\right)$ with plant spacing $20 \mathrm{~cm} \times 2 \mathrm{~cm}, 221.00 \mathrm{~m}^{3} / \mathrm{ha}$ for treatment two $\left(T_{2}\right)$ with plant spacing $30 \mathrm{~cm} \times 30 \mathrm{~cm}$ and $238.50 \mathrm{~m}^{3} / \mathrm{ha}$ for treatment three $\left(T_{3}\right)$ with plant spacing $40 \mathrm{~cm} \times 40 \mathrm{~cm}$. The mean soil erosion values were $16.87 \mathrm{~kg} / \mathrm{ha}$ for treatment one $\left(T_{1}\right), 48.03 \mathrm{~kg} / \mathrm{ha}$ for treatment two $\left(T_{2}\right)$ and $142.20 \mathrm{~kg} / \mathrm{ha}$ for treatment three $\left(T_{3}\right)$. The mean soybean yield were 13.05 tonnes/ha for treatment one $\left(T_{1}\right), 11.70$ tonnes/ha for treatment two $\left(T_{2}\right)$ and 8.25 tonnes/ha for treatment three $\left(T_{3}\right)$. The results showed that treatment one with row spacing $20 \mathrm{~cm} \times 20 \mathrm{~cm}$ produced the least runoff and soil erosion and highest soybean yield and is therefore recommended for Yandev soil in Benue State, Nigeria.
\end{abstract}

Keywords:- Plant spacing, Runoff, Soil erosion, Soybean yield.

\section{INTRODUCTION}

The problem of runoff and soil erosion and their influences on crop development and yield have continued to pose major setback in agricultural development in Nigeria. Serious attention is therefore needed for conservation and effective management of land and water [1]. Soil erosion introduces damage to the ecosystem and human society [2]. Soil erosion decreases the fertility of the soil and extends to soil degradation, affecting productivity of the soil and yield of crop [3]. Soil erosion increases the risk of sedimentation related damages and also decreases the soil water holding capacity [4]. Soil erosion increases pollution of streams and rivers with nutrients from agricultural inputs and sediments, causing eutrophication and reduction in dissolved oxygen concentration thereby causing death and migration of fish and other aquatic organisms [5]; [6]. Runoff is the portions of precipitation that finds its way towards channels, streams, rivers and oceans as surface or subsurface flow [7]. It is the quantity of water that travels on the surface of the ground to various channels and canals [8]. [9], states that, based on time delay between rainfall and runoff, it may be classified into three types, surface runoff, sub-surface runoff and base flow. The runoff rate and its volume from an area are mainly influenced by climatic and physiographic factors [8]; [7]. The climatic factors of the catchment area affecting runoff, which associate with the characteristics of precipitation are; type of precipitation, rainfall intensity, forms of precipitation, duration of rainfall, rainfall distribution, direction of prevailing wind and other climatic effects [8]; [9]; [7]. The physiographic factors of watershed are made up of, both the watershed and channel characteristics. Different features of watershed and channel, which affect the runoff are, size of watershed, shape of watershed, slope of watershed, orientation of watershed, land use, soil moisture, soil type, topographic features and drainage density [9]; [7]. Effects of runoff are both soil erosion and sedimentation, loss of cultivable land lose of fertility, pollution of water resources and deterioration of cultivated land, flood of valley bottoms and sitting of lakes [10]; [11]. Runoff can be controlled through strip cropping, contour farming, fallowing and terracing [12]; [10]. [7], methods of runoff estimation neglect some factors and make simplifying assumptions regarding the influence of others. These include rational and empirical methods. 


\section{Soil Erosion}

Soil erosion is the wearing away of land surfaces by running water, wind, ice or other geological agents including gravitational creep [13]. Soil erosion is also refers to the gross amount of soil dislodged by raindrops, overland flow, wind, ice or gravity. Soil loss is net amount of soil moved off a particular field or area [14].

[9] reported that rainfall; runoff, wind, soil, slope, plant cover and presence or absence of conservation measures are the factors, which influence the rate of soil erosion from a particular place or region. All these factors are grouped under energy, resistance and protection. The energy factor includes the potential ability of rainfall, runoff and wind to cause erosion, and those factors which directly affect the power of the erosive agents like reduction in the length of runoff or wind blow through building of terraces and bunds in case of water erosion and wind breaks or shelter belts in case of wind erosion [9]. [9], classified resistance factors as those that affect the soil erodibility. The mechanical and chemical properties of soil are counted as factors in this direction. These factors mainly encourage the infiltration rate of the soil and reduce runoff and ultimately decrease the erodibility of clay soil but increase that of sandy soil [15]. Protection factors concentrates on the plant cover. The plant covers intercepts raindrops before reaching on the ground surface and minimizes their impact on soil. The plant cover also reduces the runoff and wind velocity; as a result minimize the soil erosion [16]; [17]. Different plant covers afford different degrees of protection; therefore it is important to know the rate of soil erosion, so that a suitable plant cover can be developed by growing/planting the vegetations.

[2] reported that soil erosion affects the ecosystem and human society. Soil erosion causes destruction of soil, loss of soil fertility, reduction of water navigability and loss of crops on the field. Soil erosion can be controlled by the application of agronomic or engineering measured. The agronomic measures are the cheapest [11]. Agronomic measures are the most important control of sheet erosion where the emphasis is on reducing the extent of bare land [18]. These involves general good farming methods like growing of cover crops, use of plants and crop residue to shelter the soil from direct wind and rainfall abuses (mulching) and planting of crops in strips to provide buffer to the soil against erosion [19]. Engineering control measures are used where agronomic measures are not appropriate. These involves construction of terraces to reduce slope and channel the runoff safely to the planned drainage system, annihilation of gullies using equipment, construction of grass water ways to channel runoff from system of terraces down to natural drainage system and construction of drainage systems [7]. [7], effect of the extent of past erosion on crop yield indicates the importance of soil loss from erosion. [20], reported that the low yield observed on eroded soil is due to a decrease in the amount of water and nutrients available to plants on eroded soil. Soil loss or erosion rate can be estimated using the universal soil loss equation (USLE) [7]. Universal soil loss equation was developed from more than forty years of data measured from small plots located in many states. It is imperative to determine the adequacy of conservation measures in farm planning and to predict non-point sediment losses in pollution control programs [7].

[21], reported that agricultural activities constitute the major factors causing soil and water degradation in agricultural areas. The effect of runoff and soil erosion in cropland is very alarming and if left unchecked, will continue to reduce crop productivity. Soil disturbance due to human or animal influences can reduce vegetative cover and increase runoff and soil erosion [7]. Effects of plant spacing on runoff, soil erosion and crop yield varies from soil to soil and from one ecological zone to another, so it would be incorrect to adopt the result of plant spacing effect on runoff, soil erosion and soybean yield determined for a particular location for use in another location. It is therefore imperative to determine an accurate result of the effect in a desired location during the growing season.

The assessment of optimum spacing of soybean that would effectively control runoff and soil erosion without reducing soybean yield is required for increasing productivity of soybean, which is one of the most important sources of oil and protein in Nigeria.

The aim of this study is to establish the most suitable plant spacing that can control runoff and soil erosion but yet enhance reasonable yield of soybean in Yandev soil in Benue State, Nigeria.

\section{MATERIALS AND METHOD}

\section{$>$ Description of study Area}

The experiment was conducted at Akperan Orshi College of Agriculture, Yandev, in Gboko Local Government Area of Benue, Nigeria. Gboko local government is situated in the north of Benue State and lies between latitudes $7^{\circ} 08^{\prime}$ and $7^{\circ} 31^{\prime} \mathrm{N}$ of the equator and longitudes $8^{\circ} 37^{\prime}$ and $9^{\circ} 10^{\prime} \mathrm{E}$ of the Greenwich meridian. Akperan Orshi College of Agriculture,Yandev lies between $7^{\circ} 15^{\prime}$ and $7^{\circ} 30^{\prime} \mathrm{N}$ and along $9^{\circ} 00^{\prime}$ and $9^{\circ} 15^{\prime} \mathrm{E}$ as shown in Figure 1 . The soil of the study site is sandy with clay, silt and contents in the ratio of $88.54 \%$ sand, $3.79 \%$ clay, and $7.67 \%$ silt [22]. 


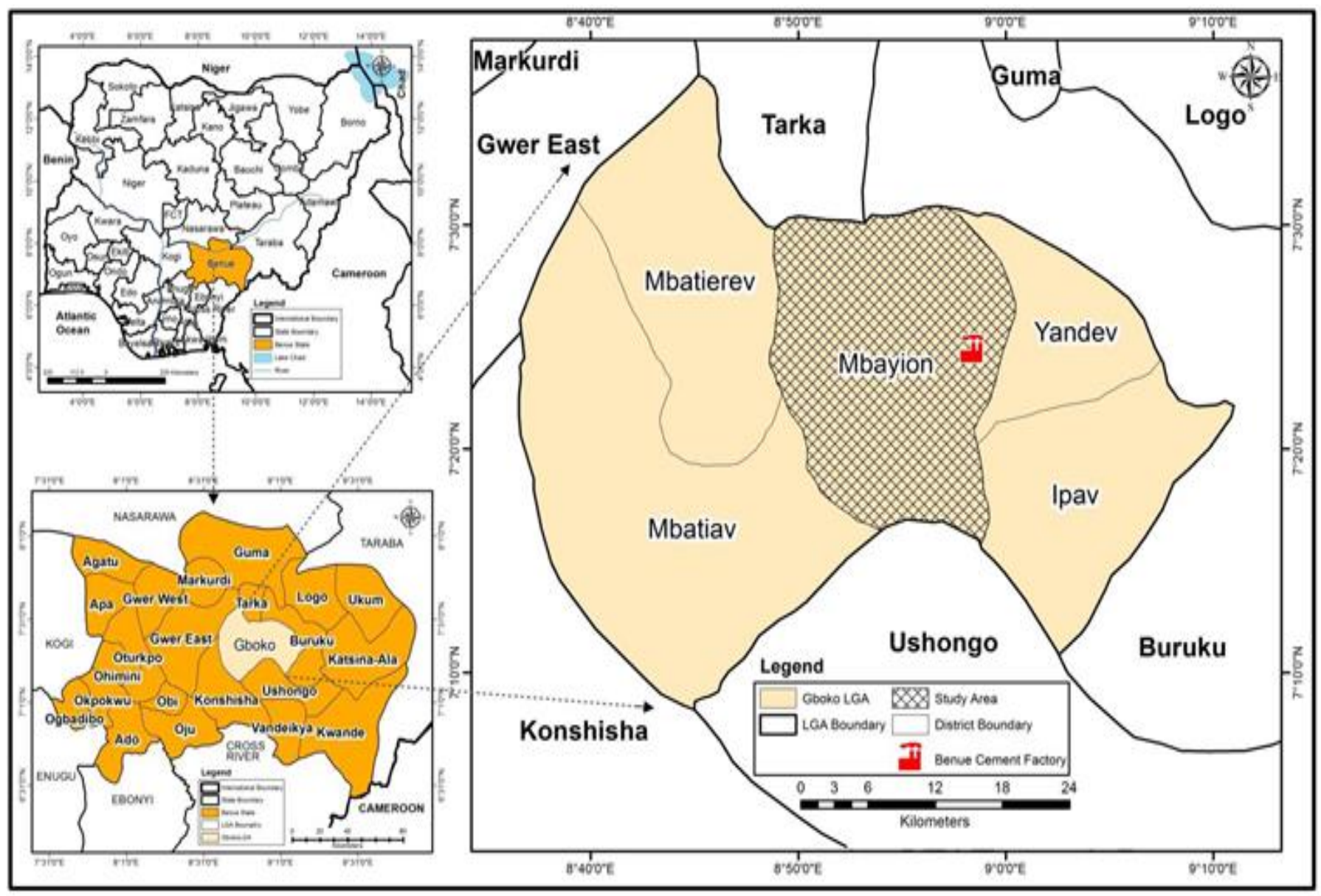

Fig 1:- Gboko LGA Showing Study Area

\section{Materials}

The materials used in the research includes burnt bricks, Potland cement, measuring tape (30m fibre glass), hoe, sharp sand zinc sheets, cutlass, digger, plastic buckets (40litres each), fertilizer (NPK 15-15-15), weighing scale (manual/electronic), measuring cylinder, water, theodolite and level.

\section{Land preparation}

The site for the experiment was cleared of its natural vegetation using hoe and cutlass with the measuring tape and pegs. The plots were measured and pegged. Nine flat beds of fine tilts each measuring $2 \mathrm{~m}$ X $1 \mathrm{~m}$ were prepared. Boundary walls of burnt bricks were built round each plot to a height $0.17 \mathrm{~m}$ to prevent runoff from entering the plots from adjacent plots and land. The boundary walls also prevent leakages out of the plots. The slope of the plot was estimated using theodolite and level to $3 \%$. Collecting pits were excavated at the lower end of each plot in the direction of the slope and plastic bucket collectors (40litres) were installed in each pit to receive runoff and eroded soil (sediment).

\section{Experimental Field Layout}

The field layout had a total area of $42 \mathrm{~m}^{2}$. The size of each micro plot was $2 \mathrm{~m} \times 1 \mathrm{~m}$ with alleyways of $0.5 \mathrm{~m}$ between treatments and $1.5 \mathrm{~m}$ between blocks. The collecting pits measured $0.6 \mathrm{~m} \times 0.6 \mathrm{~m} \times 1 \mathrm{~m}$. The experiment consisted of three treatments with three replicates, performed in a randomized complete block design (RCBD). The experimental field layout is shown in Figure 2. 


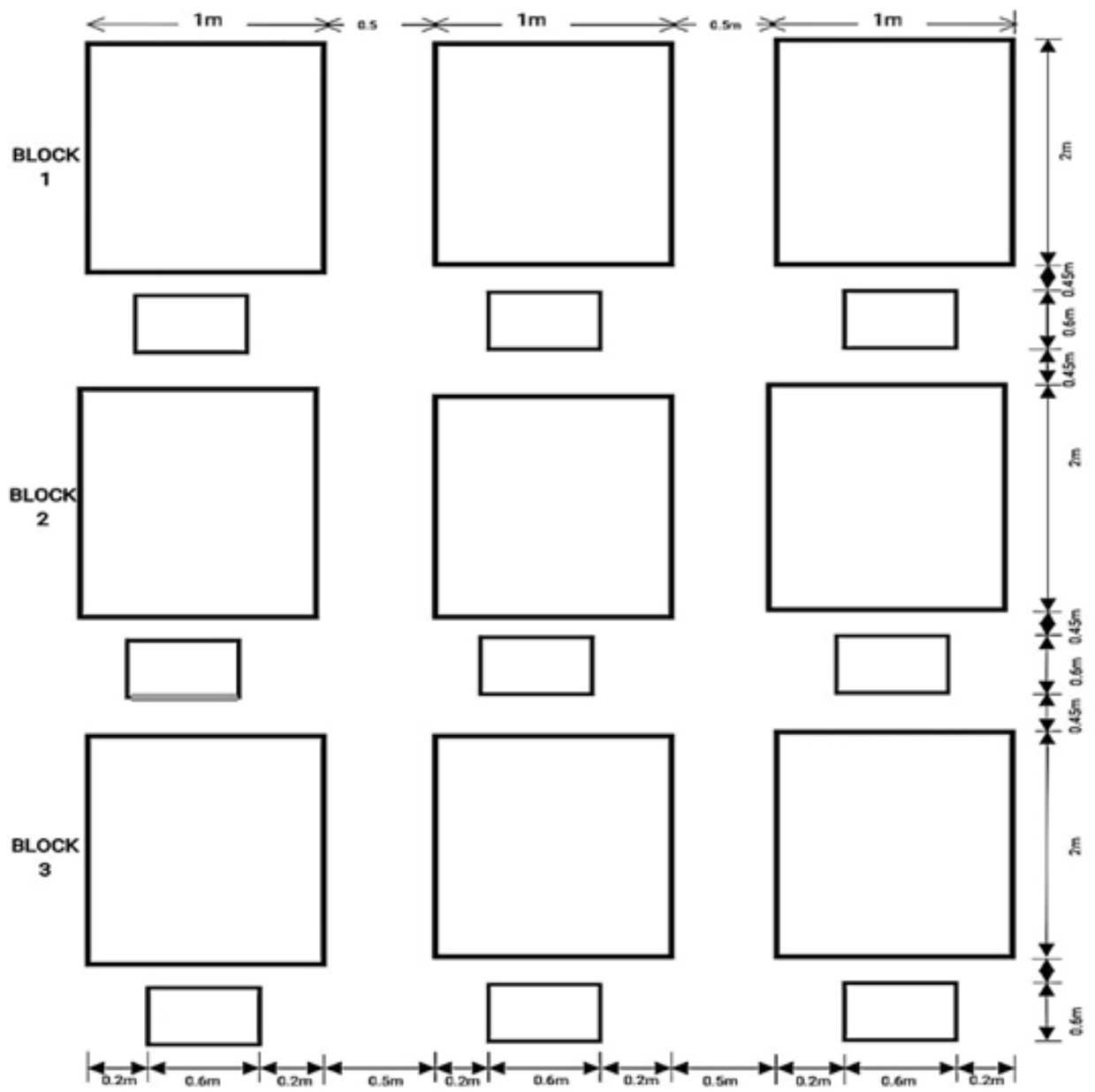

Fig 2:- Experimental Field Layout

\section{Planting and Maintenance of Soybean}

The soybean seeds (SamSoy 2) were carefully selected for viability and planted at the depth of $2 \mathrm{~cm}$ and four seeds per hole. Thinning took place two weeks after planting leaving three stands per hole.

The first weeding took place two weeks after planting. Subsequent weeding took place at two weeks interval. Weeds were removed by hand to ensure that there was no soil disturbance. The soil was stable during weeding because the weeds were handpicked. A total quantity of $0.36 \mathrm{~kg}$ of NPK $15-15-15$ fertilizer was applied evenly to each of the micro plots. The quality of fertilizer applied per micro plot was $0.04 \mathrm{~kg}$.

\section{$>$ Data Collection}

Runoff amount was assessed after each rainfall by allowing the water in the collector to sediment for 15 minutes after rainfall. The runoff water was measured using the $1000 \mathrm{ml}$ measuring cylinder. The eroded soil (sediments) was removed; oven dried and weighed using electronic weighing balance.

\section{Data Analysis}

Statistical tools were used to analyze the data. The analysis of variance (ANOVA) was performed on the sampled data. Calculation of range, mean and standard deviation of individual results obtained from the three different treatments were made. The randomized complete Block Design Model was used to compute the effects of different treatments (plant spacing) on runoff, soil erosion and soybean yield in an ANOVA at 0.05 alpha levels.

\section{RESULTS AND DISCUSSION}

\section{A. Presentation of Results}

The results of runoff, soil erosion and soybean yield obtained from each micro plot and rainfall depth after each storm and the means obtained from respective micro plots are presented in table 1 . The data obtained from each block for runoff, soil erosion and soybean yield are presented in table 2, 4 and 6. The analysis of variance (ANOVAP.0.05) for runoff, soil erosion and soybean yield are presented table in 3, 5 and 7 respectively.

\section{B. Discussion}

The total rainfall during the period of the experiment obtained from the meteorological station at Akperan, Orshi College of Agriculture, Yandev, Gboko, Benue State, Nigeria was $261.20 \mathrm{~mm}$. From table 1 , treatment one $\left(T_{1}\right)$ with row spacing $20 \mathrm{~cm} \times 20 \mathrm{~cm}$ gave the lowest rate of runoff and soil erosion followed by treatment two $\left(\mathrm{T}_{2}\right)$ with row spacing $30 \mathrm{~cm} \times 30 \mathrm{~cm}$ while treatment three $\left(\mathrm{T}_{3}\right)$ with row spacing $40 \mathrm{~cm} \times 40 \mathrm{~cm}$ gave the highest rate of runoff and soil erosion. This is because reduced spacing provides a better vegetal cover, which intercepts raindrops thereby 
reducing runoff and soil erosion. This result is in conformity with [23], and [7], who states that crop vegetal cover intercepts rainfall by absorbing the energy of the raindrop thus reducing runoff and soil erosion.

It can also be observed from table 1 that, treatment one $\left(T_{1}\right)$ with row spacing $20 \mathrm{~cm} \times 20 \mathrm{~cm}$ produced the least runoff and soil erosion and yet gave the highest yield, followed by treatment two $\left(\mathrm{T}_{2}\right)$ with row spacing $30 \mathrm{~cm} \mathrm{x}$ $30 \mathrm{~cm}$ while treatment three $\left(\mathrm{T}_{3}\right)$ with row spacing $40 \mathrm{~cm} \mathrm{x}$ $40 \mathrm{~cm}$ gave the lowest yield. This implies that, the narrower the plant spacing the higher the yield. These results conform with [23], who states that, any cropping system that ensures high and sustained yields also causes less runoff and soil erosion. Adequate crop spacing is essential for producing satisfactory yield and reducing runoff and soil erosion due to high density of crop vegetal cover produced for land protection. From table 3, 5 and 7, the analysis of variance (ANOVA $\mathrm{P}<0.05$ ) for runoff, soil erosion and soybean yield, F-ratio calculated is greater than F-ratio tabulated at alpha level five. This implies that there are significant differences among the means obtained from runoff, soil erosion and soybean yield values.

\section{CONCLUSION AND RECOMMENDATIONS}

This study established that, crop vegetal cover reduces the rate of runoff in cultivated land and that the density of crop vegetal cover in any cultivated land depends on the plant spacing. Plant spacing is a dependable factor for better yields and control of runoff and soil erosion in crop farms. In this experiment a plant spacing of $20 \mathrm{~cm} \times 20 \mathrm{~cm}$ is recommended for soybeans on Yandev sandy soil type with $3.79 \%$ clay, $7.67 \%$ silt and $88.54 \%$ sand.

\begin{tabular}{|c|c|c|c|c|c|c|c|c|c|}
\hline $\begin{array}{c}\text { Treatment/ } \\
\mathbf{R e p}\end{array}$ & $\begin{array}{c}\text { Runoff } \\
(\mathbf{m l})\end{array}$ & $\begin{array}{c}\text { Runoff } \\
(\mathbf{m m})\end{array}$ & $\begin{array}{c}\text { Runoff } \\
\left(\mathbf{M}^{\mathbf{3}}\right)\end{array}$ & $\begin{array}{c}\text { Runoff } \\
\left(\mathbf{M}^{\mathbf{3}} / \mathbf{h a}\right)\end{array}$ & $\begin{array}{c}\text { Erosion } \\
(\mathbf{g})\end{array}$ & $\begin{array}{c}\text { Erosion } \\
\mathbf{k g} / \mathbf{h a}\end{array}$ & $\begin{array}{c}\text { Soybean } \\
\text { Yeld }(\mathbf{k g})\end{array}$ & $\begin{array}{c}\text { Soybean } \\
\text { Yeld } \\
(\mathbf{k g} / \mathbf{h a})\end{array}$ & $\begin{array}{c}\text { Soybean } \\
(\mathbf{t o n n e s} / \mathbf{h a})\end{array}$ \\
\hline & & & & & & & & & \\
\hline $\mathrm{T}_{1} \mathrm{R}_{1}$ & $13,780.00$ & 6.89 & 0.0137 & 68.50 & 3.30 & 16.50 & 2.65 & 13250 & 13.25 \\
\hline $\mathrm{T}_{1} \mathrm{R}_{2}$ & $14,142.00$ & 7.07 & 0.0141 & 70.50 & 2.83 & 14.15 & 2.70 & 13500 & 13.50 \\
\hline $\mathrm{T}_{2} \mathrm{R}_{1}$ & $12,793.00$ & 6.39 & 0.0127 & 63.50 & 3.99 & 19.95 & 2.48 & 12400 & 12.40 \\
\hline $\mathrm{T}_{2} \mathrm{R}_{1}$ & $13,924.00$ & 6.96 & 0.0139 & 69.50 & 7.18 & 35.90 & 2.50 & 12500 & 12.50 \\
\hline $\mathrm{T}_{2} \mathrm{R}_{2}$ & $15,232.00$ & 7.62 & 0.0152 & 76.00 & 13.89 & 69.45 & 2.40 & 12000 & 12.00 \\
\hline $\mathrm{T}_{2} \mathrm{R}_{3}$ & $15,107.00$ & 7.55 & 0.0151 & 75.50 & 7.75 & 38.75 & 2.12 & 10600 & 10.60 \\
\hline $\mathrm{T}_{3} \mathrm{R}_{1}$ & $15,722.00$ & 7.86 & 0.0157 & 78.50 & 15.71 & 78.55 & 1.75 & 8750 & 8.75 \\
\hline $\mathrm{T}_{3} \mathrm{R}_{2}$ & $16,994.00$ & 8.49 & 0.0169 & 84.50 & 46.16 & 230.80 & 1.68 & 8400 & 8.40 \\
\hline $\mathrm{T}_{3} \mathrm{R}_{3}$ & $15,124.00$ & 7.56 & 0.0151 & 75.50 & 23.45 & 117.25 & 1.52 & 7600 & 7.60 \\
\hline
\end{tabular}

Table 1:- Mean Runoff, Erosion and Soybean Yield

\begin{tabular}{|c|c|c|c|c|c|}
\hline Treatment & $\mathbf{B}_{1}$ & $\mathbf{B}_{2}$ & $\mathbf{B}_{3}$ & Total & Mean \\
\hline 1 & 68.50 & 70.50 & 63.50 & 202.50 & 67.50 \\
\hline 2 & 69.50 & 76.00 & 75.50 & 221.00 & 73.66 \\
\hline 3 & 78.50 & 84.50 & 75.50 & 238.50 & 79.50 \\
\hline Total & $\mathbf{2 1 6 6 . 5 0}$ & $\mathbf{2 3 1 . 0 0}$ & $\mathbf{2 1 4 . 5 0}$ & $\mathbf{6 6 2 . 0 0}$ & $\mathbf{2 2 0 . 6 6}$ \\
\hline Mean & $\mathbf{7 2 . 1 7}$ & $\mathbf{7 7 . 0 0}$ & $\mathbf{7 1 . 5 0}$ & $\mathbf{2 2 0 . 6 7}$ & \\
\hline
\end{tabular}

Table 2:- Mean Runoff values ( $\left.\mathrm{m}^{3} / \mathrm{ha}\right)$ from each Block

\begin{tabular}{|c|c|c|c|c|c|c|}
\hline $\begin{array}{c}\text { Source } \\
\text { Variation }\end{array}$ & $\begin{array}{c}\text { Degree of } \\
\text { freedom }\end{array}$ & $\begin{array}{c}\text { Sums of } \\
\text { squares }\end{array}$ & Mean squares & Fcal & Ftab (0.05) & Ftab (0.01) \\
\hline Block & 2 & 54.06 & 27.03 & 2.69 & 6.94 & \\
\hline Treatment & 2 & 216.06 & 108.03 & 10.77 & 6.94 & \\
\hline Error & 4 & 40.11 & 10.03 & & & \\
\hline Total & $\mathbf{8}$ & $\mathbf{3 1 0 . 2 3}$ & $\mathbf{3 8 . 7 5}$ & & & \\
\hline
\end{tabular}

Table 3:- ANOVA for Runoff Data $\left(\mathrm{m}^{3} / \mathrm{ha}\right)$

\begin{tabular}{|c|c|c|c|c|c|}
\hline Treatment & $\mathbf{B}_{\mathbf{1}}$ & $\mathbf{B}_{\mathbf{2}}$ & $\mathbf{B}_{\mathbf{3}}$ & Total & Mean \\
\hline 1 & 16.50 & 14.15 & 19.95 & 50.60 & 16.87 \\
\hline 2 & 35.90 & 69.45 & 38.75 & 144.10 & 48.03 \\
\hline 3 & 78.55 & 230.80 & 117.25 & 426.60 & 142.20 \\
\hline Total & $\mathbf{1 3 0 . 9 5}$ & $\mathbf{3 1 4 . 4 0}$ & $\mathbf{1 7 5 . 9 5}$ & $\mathbf{6 2 1 . 3 0}$ & $\mathbf{2 0 7 . 1 0}$ \\
\hline Mean & $\mathbf{4 3 . 6 5}$ & $\mathbf{1 0 4 . 8 0}$ & $\mathbf{5 8 . 6 5}$ & $\mathbf{2 0 7 . 1 0}$ & \\
\hline
\end{tabular}

Table 4:- Mean Erosion values (kg/ha) 


\begin{tabular}{|c|c|c|c|c|c|c|}
\hline $\begin{array}{c}\text { Source } \\
\text { Variation }\end{array}$ & $\begin{array}{c}\text { Degree of } \\
\text { freedom }\end{array}$ & $\begin{array}{c}\text { Sums of } \\
\text { squares }\end{array}$ & Mean squares & Fcal & Ftab (0.05) & Ftab (0.01) \\
\hline Block & 2 & 6094.15 & 3047.07 & 1.71 & 6.94 & \\
\hline Treatment & 2 & 25547.17 & 12773.59 & 7.16 & 6.94 & \\
\hline Error & 4 & 7138.73 & 1784.68 & & & \\
\hline Total & $\mathbf{8}$ & $\mathbf{3 8 7 8 0 . 0 5}$ & $\mathbf{4 8 4 7 . 5 1}$ & & & \\
\hline
\end{tabular}

Table 5:- ANOVA for Erosion Data (Kg/ha)

\begin{tabular}{|c|c|c|c|c|c|}
\hline Treatment & $\mathbf{B}_{\mathbf{1}}$ & $\mathbf{B}_{\mathbf{2}}$ & $\mathbf{B}_{\mathbf{3}}$ & Total & Mean \\
\hline 1 & 13.25 & 13.50 & 12.40 & 39.15 & 13.05 \\
\hline 2. & 12.50 & 12.00 & 10.60 & 35.10 & 11.70 \\
\hline 3. & 8.75 & 8.40 & 7.60 & 24.75 & 8.25 \\
\hline Total & $\mathbf{3 4 . 5 0}$ & $\mathbf{3 3 . 9 0}$ & $\mathbf{3 0 . 6 0}$ & $\mathbf{9 9 . 0 0}$ & $\mathbf{3 3 . 0 0}$ \\
\hline Mean & $\mathbf{1 1 . 5 0}$ & $\mathbf{1 1 . 3 0}$ & $\mathbf{1 0 . 2 0}$ & $\mathbf{3 3 . 0 0}$ & \\
\hline
\end{tabular}

Table 6:- Mean soybean yield values (tonnes/ha)

\begin{tabular}{|c|c|c|c|c|c|c|}
\hline $\begin{array}{c}\text { Source } \\
\text { Variation }\end{array}$ & $\begin{array}{c}\text { Degree of } \\
\text { freedom }\end{array}$ & $\begin{array}{c}\text { Sums of } \\
\text { squares }\end{array}$ & Mean squares & Fcal & Ftab (0.05) & Ftab (0.01) \\
\hline Block & 2 & 2.94 & 1.47 & 16.33 & 6.94 & 6.94 \\
\hline Treatment & 2 & 36.77 & 18.39 & 204.33 & \\
\hline Error & 4 & 0.36 & 0.09 & & \\
\hline Total & $\mathbf{8}$ & $\mathbf{4 0 . 0 7}$ & $\mathbf{5 . 0 1}$ & & \\
\hline
\end{tabular}

Table 7:- ANOVA for Soybean yield Data (tonnes/ha)

\section{REFERENCES}

[1]. Chia, V.D and C.C Mbajiorgu (2018) A comparative study of KINEROS2 and AGNPS Models in the Estimation of Runoff and sediment yield from an agricultural watershed. Nigerian Journal of Hydrological sciences Vol. 6, 2018 pp.3649.ISSN: 2315-6686.

[2]. Mengjing, G; Tiegang, Z; Zhanbin, L; and Guoce, X (2019) investigation of Runoff and sediment yields under different crop and tillage conditions by field artificial rainfall experiments.

[3]. Assouline, S. and Ben Hur, M (2006) effects of rainfall intensity and slope gradient on the dynamics of interill erosion during soil surface sealing. Catena 2006, 66, 211-220

[4]. Shi Z.H; Fang, N.F; Wu, F.Z; Wang, L; Yue, B.J.; and $\mathrm{Wu}, \mathrm{G} . \mathrm{L}$ (2012) soil erosion processes and sediment sorting associated with transport mechanisms on steep slopes. J. Hydrol. 2012, 454-455, 123-130.

[5]. Aga and Anyadike (2019) Modeling the water quality of point and diffuse source pollutants in Ngo River in Nigeria. Proceedings of the $2^{\text {nd }}$ conference/workshop sson Renewable Energy for Domestic and industrial Applications Organized by National centre for equipment maintenance and Development (NCEMD) in collaboration with: The Bio- resources, Renewable Energy and environmental control Engineering (BREEE)

Research group, university of Nigeria, Nsukka. $31^{\text {st }}$ March- $4^{\text {th }}$ April, 2019. Pp122-132.
[6]. Wu, L; Long, T.Y.; Liu, X.; and Guo. J.S (2012) impacts of climate and land use changes on the migration of non-point source nitrogen and phosphorus during rainfall-runoff in the Jialing river watershed, china. Journal of Hydrdogy. 2012, 475, 26-41.

[7]. Schwab, G.O., Elliot, W.J; Fangmeier, D.D and R.L Huffman (2011) soil and water conservation Engineering sixth edition. ISBN 1892769-79-4 LCCN

2011912729 ASABE publication 801M0411 Pp.530

[8]. Arora K.R. (1996). Irrigation water power and water resources engineering standard publishers and distribution, Delhi Pp. 260-307

[9]. Suresh, R. (1993). Soil and water conservation Engineering $4^{\text {th }}$ Edition pp 335-347

[10]. Hudson, N.W. (1993). Field measurement of soil erosion and runoff FAO soil Bulletin Vol. 1 Pp 111113.

[11]. Duru R.U; Ogoni, H.A; Okonkwo, O.C (2001). A complication contemporary environmental research. African Journal of Environmental studies 2 (1): 104.

[12]. Zhang, J., Wang, T; and Ge, J. (2015), Assessing vegetation cover dynamics induced by policy driven ecological restoration and implication to soil erosion in southern china PLo SONE 2015, 10, e 0131352.

[13]. SCSA (1982). Resources conservation Glossary $3^{\text {rd }}$ edition. Soil conservation society of America. An Kery, 10WA. Vo1.1 Pp.193. 
[14]. Mitchell, JK; Bubenger, R.C and Schertz, D.L. (1980). Soil loss Estimation, wiley chichester England. Pp17

[15]. Zhang, M.L; Yang, H; Zou., Liang-Jiang, X.u; and Sui, Z.L. (2011) Effects of soil erosion on soil quality in the rocky mountain areas of northern china $\mathrm{J}$. soil water conserv 2011, 2, 218-221.

[16]. Li, P., Cai, W., Zheng, L; and Ru, H. (2006). Effects of vegetation on runoff hydraulic characteristics and erosion. Sci. soil water conserv. 2006, 4, 55-59

[17]. Loch, R.J: Loch, R; and Jasper, D (2000). Effects of vegetation cover on runoff and erosion under simulated rain and overland flow on a rehabilitated site on the meandu mine, tarong, queensland. Aust. J. soil Res. 2000, 38, 299312.www.mdpi.com/journal/water.water2019,11,1019 ;doi:10.3390/w11051019

[18]. Samaniego, L; and Bardossy A. (2006). Simulation of the impact of land use/cover and climatic changes on runoff characteristics at eh mesoscale. Ecol. Model. 2006, 196,45-61.

[19]. Liu, Y; Tao, Y; Wan, K.Y; Zhang, G.S; Liu D.B; Xiong, G.Y; and Chen, F. (2012). Runoff and nutrient losses in citrus orchards on sloping land subjected to different surface mulching practices int eh danjiangkou reservoir area of china. Agric. Water Manag. 2012, 110, 34-40.

[20]. Schertz, D.L; Sneal, T.H. and Voznesensky, A.S. (1982). Effect of past erosion on crop productivity in India. Journal of soil and water conservation. Vol. 1 pp $604-608$.

[21]. Ogwo, V., Mbajiorgu, C.C; Ogbu, K.N; and Ndulue, L.E. (2018) Stream flow and sediment yield prediction using Ann AGNPS model in upper Ebonyi River watershed, Enugu state, Nigeria. Nigerian Journal of Hydrological Sciences Vol. 6, 2018. Pp 68-88.

[22]. Ukah, O.I, D. I. Akaaimo and D. I. Edoh (2001), Predicting the potential Soil loss for Gboko Local Government Area of Benue State, Nigeria. J. of Agric. And Related Sciences, 1(1): 1- 6

[23]. Lal, R. (1990), Soil Erosion in the Tropics, Principles and Management. Mc. Grew-Hill New York Pp.270 